\title{
Impulso dramático entre Carlos de Oliveira e João Cabral de Melo Neto
}

Leonardo Gandolfi

UNIFESP

\begin{abstract}
Resumo
Identificar, no impulso dramático de alguns textos de Carlos de Oliveira e João Cabral de Melo Neto, formas de visão performativa da voz através da escrita. Aspectos performativos da voz em sua relação processual com o drama, forma de corporeidade submetida ao papel. Leitura de certa experiência dramática de Carlos de Oliveira em textos de difícil classificação como gêneros literários. Analogia entre o adiamento do teatro praticado pelo autor e o compromisso político em literatura. Em João Cabral, análise dos elementos vocálicos em Dois Parlamentos e em Auto do Frade, relacionando-os à fusão entre a voz da personagem Cabral e de outras personagens nos poemas. Tensão entre ordem e desordem, desdobrada em tensão entre construtivismo e seu consequente extravio.

Palavras-chave: João Cabral de Melo Neto; Carlos de Oliveira; poesia portuguesa; poesia brasileira; neorrealismo.
\end{abstract}

\begin{abstract}
The text is about dramatic aspects or dramatic impulse of some poems by Carlos de Oliveira and João Cabral de Melo Neto, the voice's performativity in poems. In João Cabral, the analysis of vocalic elements in the dramatic poems Dois Parlamentos and Auto do Frade. The fusion between the voice of the character Cabral and other characters in those poems. The tension between order and disorder splitted into tension between constructivism and its consequent defeat. On the other hand, the dramatic experience in Carlos de Oliveira's texts are difficult to classify only as dramatic genre. Analysis of the relation between the unwritten plays by the author and his political commitment in literature.

Key-words: João Cabral de Melo Neto; Carlos de Oliveira; portuguese poetry; brazilian poetry; neorealism.
\end{abstract}


1. OTTONI, Paulo. "John Langshaw Austin e a visão performativa da linguagem", 2002, p. 120.

2. NETO, João Cabral de Melo. A educação pela pedra e outros poemas, 2008, pp. 67-68.

3. Ibidem, p. 69.
Os textos de João Cabral de Melo Neto e Carlos Olivei$\mathrm{ra}$, ainda que de maneiras diferentes entre si, encenam um tipo de visão performativa da voz através da escrita. Ou seja, pode-se dizer que os autores encaram a voz ou a vocalidade escrita como uma forma de dar ação, corpo, temporalidade, performance ao texto no papel. Por exemplo, quando pensa na relação voz e texto, Austin guarda muita coisa em comum com certa concepção de poesia moderna em que é a palavra a principal parte do acontecimento de um fato. Para o linguista, segundo Paulo Ottoni, as "afirmações agora não só dizem sobre o mundo como fazem algo no mundo. Não descrevem a ação, praticam-na"1. Não à toa, Paul Zumthor também dá à voz certo aspecto performativo, quando a relaciona ao canto e ao drama, extensões da voz dita. Portanto, quando submetidos ao papel, também se mostram como formas de fisicalidade, movimentação e tempo do texto.

Um desdobramento da questão da voz em Cabral e Oliveira é o canto, por exemplo, "A Palo Seco", poema publicado no livro Quaderna, de 1960, por Cabral: "O cante a palo seco/ é um cante desarmado:/ só a lâmina da voz/ sem a arma do braço;// que o cante a palo seco/ sem tempero ou ajuda/ tem

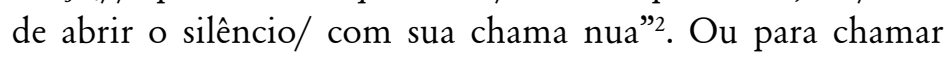
mais atenção da relação entre o silêncio da escrita, a voz do canto e a relação da contaminação de ambas através do tempo: "Ou o silêncio é levíssimo, / é liquido sutil/ que se coa nas frestas/ que no cante sentiu;// o silêncio paciente/ vagaroso se infiltra,/ apodrecendo o cante/ de dentro, pela espinha"3. Há outros desdobramentos que também ressaltariam os aspectos performativos, i.e., gestuais da voz escrita; entre eles estão, por exemplo, a presença da dança ou ainda de forma mais evidente o do drama.

Neste texto, percorrerei alguns momentos das obras dos autores em questão valori-zando tal aspecto performativo da voz em sua relação processual com o drama, tipo de extensão da voz escrita, ou melhor, forma de fisicalidade corporal submetida ao papel. A respeito disso, quando se pensa em João Cabral, fala-se imediatamente dos poemas cujas vozes têm função dramática imediata como no caso de Morte e Vida Severina e Auto do Frade: o primeiro, um auto de natal de feição popular e medieval; o segundo, um poema para vozes que lança outro olhar sobre um fato histórico de Pernambuco. Ao se pensar em Carlos de Oliveira, não se encontram textos que, para além do recurso da voz, assumem o dramático como influência direta. No entanto, em um texto de $O$ Aprendiz de Feiticeiro, "O inquilino", o autor apresenta o teatro como gênero não conseguido: "Sempre pensei escrever teatro. Durante anos fui acumulando ideias, títulos, esquemas, livros de consulta. Mas hoje, olhando para trás, verifico que a minha obra teatral tem 
muita coisa inútil, para pôr parte, e reduzo-a a duas peças principais"4. E a seguir descreve as duas peças que constituiriam sua obra dramática: $A$ Barragem e Mrs. Davies, mas apenas descreve-as, não apresenta nenhum trecho. Antes disso, no entanto, Oliveira, neste mesmo texto - que está dividido em três partes - apresenta o que seria $O$ inquilino, espécie de esboço de poema dramático. Apesar de integrar "O Inquilino", texto maior de $O$ Aprendiz de Feiticeiro, Oliveira não inclui este $O$ inquilino na sua descrição de obras teatrais. Um parêntese para a diferença entre "O Inquilino", texto dividido em três partes de $O$ Aprendiz de Feiticeiro, e $O$ inquilino, primeira parte desse texto maior "O Inquilino". Como disse, ele não o inclui, simplesmente o apresenta, para além de classificações. Segue então o início do texto na íntegra:

Ainda me lembro dessa noite. Fevereiro de mil novecentos e cinquenta e quatro. Sentado à mesa de trabalho, sem fazer gesto, recortado na luz intensa do candeeiro que o apanhava de perfil, o inquilino ia perguntando aos espectadores imaginários como se o tolhesse a lentidão dum sonho ou o tapete no fio se pusesse de repente a falar: ${ }^{5}$

A partir daí, segue-se um trecho em verso que seria a fala do inquilino em resposta a uma suposta fala do "tapete no fio" ou seria a própria fala do "tapete no fio", o fim do parágrafo acima dá margens à ambiguidade: "Aceito a ordem/ das coisas, a geometria/ imposta do quarto?"6. Depois de uma lista descritiva dos objetos que compõe a cena onde trabalha um escritor - "Os objectos no/ seu lugar de sempre,/ a distância exacta/ da cadeira à mesa/ do meiple à janela?” - surge uma pergunta desconcertante, na medida em que atribui a relação da disposição entre ele, escritor, e seus objetos um caráter transformador: "Aceito a minha vida?/ Ou mexo no candeeiro,/ desvio-o alguns centímetros/ na mesa, altero/ as relações das coisas,/ afinal tão frágeis/ que o simples desvio/ dum objecto pode/ romper o equilíbrio?”7 . Está aqui um processo já conhecido em Oliveira, a do desvio ligado à vida, que se desdobra na ideia do frágil equilíbrio que ao mesmo tempo une e separa a tudo. Conforme o sujeito interage com os objetos, estes vão deslocando aquele: "Desloco o cinzeiro/ sabendo que posso/ matar mandarins,/ provocar cataclismos,/ fracturas, amores,/ eclipses, sonhos,/ com a ponta dum dedo?" do jogo com a leitura da novela ${ }^{9}$ de Eça de Queiroz, a fusão (confusão) se dá: “(...) Confundo/ o aluguer e o tempo,/ deixo-me ser/ em cada milímetro,/ em cada segundo,/ do quarto, da vida,/ o outro objeto/ chamado inquilino?” ${ }^{10}$.

Não sei se a confusão se dá entre o escritor e o inquilino, como se não pudessem fazer parte de uma mesma instância, ou entre os próprios objetos e o inquilino, que no caso assume
4. OLIVEIRA, Carlos. $O$ aprendiz de feiticeiro, 2004, p. 33.

5. Ibidem, p. 31.

6. Ibidem, p. 31 .

7. Ibidem, p. 32.

8. Ibidem, p. 32.

9. $O$ mandarim, publicado em 1880.

10. Ibidem, p. 33. 

11. Ibidem, p. 33.
12. Ibidem, p. 34.
13. Ibidem, p. 34.

mais características de objetos do que de sujeito. O que legitimaria o fato de a fala ser do "tapete no fio". A continuação, por ser mesmo alternativa, só confirma que a coisa se dê no âmbito de uma dúvida, de uma hipótese: "Ou desencadeio/ a insurreição/ mudando de sítio/ o meiple, a cadeira,/ mudando-me a mim?" 11 . A hipótese é a seguinte: ou o objeto se transforma em inquilino ou o deslocamento, "insurreição", transporta o sujeito dele a ele mesmo através dos objetos, mudando os objetos de "sítio", "mudando-me a mim". Em termos formais, $O$ inquilino não é propriamente nem um texto dramático, nem um poema dramático, mas um texto, despido do caráter de um gênero específico, que tem fortes elementos dramáticos, com um parágrafo em prosa anunciando a voz que fala em verso.

Sobre "A barragem", Oliveira fala nos termos de uma "tragédia revolucionária”. Fala dos textos do teatro histórico português moderno com os quais a peça se relacionaria, entre eles, "El-Rei Sebastião", de José Régio, e “O Indesejado", de Jorge de Sena. Chama muita atenção o comentário que ele faz sobre o tal sentido trágico da peça, que curiosamente guarda relação com o que Eduardo Lourenço chamou um dia de trágico neorrealista:

O sentido trágico está no facto dos personagens não terem outra oportunidade e se falharem irremediavelmente. A experiência da derrota, o envolvimento nos preparativos dum vale de Josafat político, de juízo final sem apelo nem agravo, a construção da barragem, lenta, cheia de perigos (...), instalam nestes homens que esperam a ressurreição ou a segunda morte, definitiva mesmo para os católicos, uma grande solidão interior que a peça explora em todos os sentidos: metafísico, histórico, religioso, social, militante. Cálculos quase infinitesimais da consciência humana sondando seu significado, o seu destino ${ }^{12}$.

A peça, no entanto, é um objeto ausente, ela é apenas mencionada pelo autor. Ao fim deste anúncio, aliás, surge uma espécie de corpo estranho, Oliveira inicia uma bela e ecológica declaração de amor a Gelnaa, personagem interlocutora, duplo anagramático da esposa do escritor, Ângela de Oliveira. Tal personagem, durante o livro, muitas vezes representa aqueles "espectadores imaginários" a que o autor faz referência no parágrafo de $O$ Inquilino. A referência deslocada começa ainda no âmbito do comentário da peça:

Faltam alguns com certeza [títulos, a partir da lista que ele fez de textos teatrais que dialogariam de certa forma $\operatorname{com} A$ Barragem], mas cito de memória, sem estantes para consultar, neste ermo dos arredores de Lisboa batido por um vento de tempestade que vai derrubando centenas de pinheiros, colaborando exemplarmente no arboricídio geral ${ }^{13}$. 
A necessidade de falar da memória leva-o a falar do lugar de onde fala, e a este lugar ele atribui características negativas, "ermo" e "batido", é o desenvolvimento dessas características negativas que o leva a abordar o tema propriamente ecológico do "arboricídio", que é "geral”. Chamo atenção para a palavra "geral”, que transfere esse carácter destrutivo não apenas para as árvores, mas para o ambiente como um todo que circunda o autor. Referi-me a este trecho como corpo estranho na medida em que ele não se relaciona diretamente com o que foi dito antes sobre $A$ Barragem. É difícil pensar que um autor como Carlos de Oliveira - que tanto presa pelo rigor construtivo produzisse essa espécie de ruído textual gratuitamente. Julgo que o efeito do negativo do "arboricídio geral" junto do "ermo dos arredores" tem algo a ver com o teatro adiado ou abandonado por Oliveira, como aquela beleza postergada em nome de uma poesia de combate, que curiosamente fez do seu maior combate o silêncio ou a lamentação plangente por não cantar a beleza. Beleza a que Oliveira faz referência logo a seguir no mesmo trecho: "Plantaremos outra acácia, claro, mas a que foi derrubada deixou um pouco de sombra nos olhos de Gelnaa. Uns olhos que escurecem de ano para ano"14. E sob este mesmo signo da perda vem um dos momentos mais bonitos de todo O Aprendiz de Feiticeiro, endereçado a espectadora Gelnaa:

São as tuas rugas, costumo dizer-lhe. E penso: por enquanto. O tempo não lhe tocou ainda (por enquanto, repito superticiosamente, como se o orgulho que sinto ao vê-la, sem esta ressalva, pudesse trazer mais cedo a velhice), limitou-se a carregar-lhe a íris do negro quase verde que têm os abismos em torno da sua ilha ${ }^{15}$.

Repito: é curioso que ele faça uma reflexão, como essa, sobre o tempo, a beleza e a morte, logo após contar sobre a peça que ele desistiu de fazer. Como eu disse, essa aproximação do teatro ou da dança - que em sua obra são formas de materialização da voz - tem um quê de consciência da finitude que sempre acompanhou o autor, mas que fica mais evidente em um livro como Entre Duas Memórias e encontra seu auge em Finisterra e Pastoral. Mais à frente, na terceira parte de "O Inquilino", o autor fará breve aproximação do comentário sobre o "arboricídio geral" e a peça inexistente, através de um curioso dado biográfico, que funcionará como justificativa. Mais à frente também, comento tal aproximação. A segunda e última peça de Oliveira é sobre uma mulher sul-africana - paixão adolescente de Fernando Pessoa e a quem ele teria escrito seus poemas "obscenos" Antinous e Epithalamium - que desembarca em Lisboa para ver o poeta "já agonizante" morrer no hospital: "E no entanto Mrs. Davies vem procurá-lo, no cumprimento de uma promessa que pesou na existência e na obra de Pessoa
14. Ibidem, p. 35.

15. Ibidem, p. 35. 
16. Ibidem, p. 38.

17. Ibidem, p. 34.

18. Ibidem, p. 38

19. Ibidem, p. 39

20. Ibidem, p. 39.

21. PEIXOTO, Níobe Abreu. João Cabral e o poema dramático, 2001, p. 17.

22. ALVES, Ida Maria Santos Ferreira. "O aprendiz de feiticeiro: a máquina nos meus olhos”, 2011, p. 142. até à bulia, até ao génio, só para ele a rever e se rever uma última vez"16. A pulsão ficcional nesta peça de teatro adiado ou abandonado é tão grande quanto, novamente, o cantar a distância temporal que dá espessura à memória, espessura à consciência do fim.

Os dois textos dramáticos, que só existem como "uma promessa" não cumprida, ou melhor, como "experiência da derrota" 17 ou como impulso: "O mais curioso destas peças é nunca terem sido escritas"18 ou "(...) mal chegava o momento de escrever, o tal minuto da verdade, logo o diabo ou o anjo sem rosto me suspendia a mão"19 (Ibidem, p.39). Logo após escrever isso, Oliveira retorna a $O$ Inquilino e diz que este teria sido o único texto de toda sua obra em que ele chegou perto do que se pode chamar inspiração. No entanto, ao se permitir essa aproximação, ele sentiu de certa maneira que isso era uma forma de "ferir o equilíbrio do mundo ou coisa parecida" ${ }^{20}$. Por isso, ao olhar pela janela, ele se depara com uma tempestade de neve em Lisboa. Como se o descontrole das palavras - caso que ocorreu na escrita de um texto dramático - tivesse tornado descontínua a linha tênue que pode ordenar o mundo em constante transformação empreendida por Carlos de Oliveira.

Nisso Oliveira e Cabral são realmente muito próximos. Ambos têm no rigor um tipo de expurgação, o rigor como uma forma de equilibrar forças, o combate pensado - construído na obra - a uma ameaça natural e própria, que também pertence à obra, espécie de antídoto. $\mathrm{O}$ mais interessante é que tal rigor não tem sentido sem essa força dispersiva, é quase como se rigor e dispersão se compensassem. Sobre Cabral, Alcides Villaça chega mesmo a falar "na força maior do drama" que sua "voz poética programaticamente represada" contém ${ }^{21}$. O movimento gerado no interior dos textos é justamente o jogo de forças entre esses pares que nunca existiram isolados e que só existem como tensão e atrito. Ora caminha-se numa direção; ora, noutra; mas nunca se fica parado. É dessa ordem a força subjetiva-objetiva que fala no texto dos dois, entre o controle da indistinção no limite de romper-se, ou rompendo, como no caso da tempestade de gelo acima, ampliando as sombras nos olhos de Gelnaa (efeito do tempo). E tal jogo de força, de modos diferentes em um e no outro, se dá através da dinâmica entre a voz-corpo e a escrita-silêncio, presente nos dois.

Ida Alves - ao analisar nos termos de uma "busca" em que "o sujeito reconheça o fracasso do reencontro", o potencial imagético dos livros de Carlos de Oliveira - anota como "em sua obra o ato gráfico, material, físico, mesmo de escrever é dramatizado" 22 . Em relação ao dramático, trata-se de um enquadramento mais específico na obra do autor que flagra tal acento nas diversas encenações do ato de escrever e ler ou de 
maneira mais geral: "Dramatiza-se, ao fim e ao cabo, o ato de ver (assiste-se a), de contemplar o filme interior da memória e o mundo exterior tão duramente concreto" ${ }^{23}$. Ou seja, em Oliveira se está sempre diante de um mundo em construção/destruição, mas antes disso se está diante de alguém que faz parte dessa construção/destruição do mundo, não apenas como testemunha, mas como agente. Depois, Ida Alves coloca essa pulsão dramática entre "as obsessões processuais que atravessam $O$ Aprendiz de Feiticeiro e se disseminam pelo conjunto da obra" 24 . Pensar esse acento dramático como uma "obsessão processual” é bem-vindo, pois relativiza o drama e a própria lírica como gêneros independentes e ainda - como processo que é - inclui no sistema, da qual o mesmo processo faz parte, elementos de estranheza que colaboram para a concatenação de fenômenos desse sistema, mas, ao mesmo tempo, introduzem nele descontinuidades que o impedem de seguir uma direção sempre definida. Nesse sentido, poderia se falar desse acento dramático como uma obsessão processual não só de Carlos de Oliveira, mas também de João Cabral na medida em que o teatro em sua obra, nomeadamente, ganhou mais espaço que na obra de Oliveira.

O teatro inacabado e indefinidamente adiado no autor português pode ter a mesma dimensão do que o próprio Oliveira falou certa vez sobre Osório Bastos, "futuro romancista, de 38 anos, grisalho, casado, pai de um filho, autor de comentários para curtas metragens e outra literatura cinematográfi-

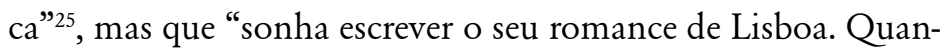
do, não se sabe?”. Osório Bastos é um personagem de Enseada Amena, romance de Augusto Abelaira. Para além da resenha que Oliveira faz do romance, interessa esta aproximação que ele faz da personagem: "O que me interessa aliás em Osório Bastos não é o escritor frustrado mas seu 'adiar', embora seja difícil pôr a frustração ali e o resto aqui, bem separados”26. Carlos de Oliveira interessa-se por um constante “adiar”, do qual não separa a frustração, porque ele também vive várias formas de adiamento. As mais famosas são: "Hei-de cantar-vos a beleza um dia" 27 e "Cantar/ é empurrar o tempo ao encontro das cidades futuras/ fique embora mais breve a nossa vida" 28 . A esses dois trechos - que lidam com o dilema do caráter de intervenção social das artes - acrescento: "Será da própria condição das coisas serem silenciosas agora?" 29 . O adiamento da personagem Osório Bastos e o adiamento do teatro em Oliveira são faces de uma mesma moeda, a moeda do sacrifício do presente em prol do futuro: "quando se adia o amor, a acção política, o romance a escrever (...) Osório fica assim diante de um dilema incómodo: ou poupar a juventude ou vivê-la" ${ }^{30}$. Porque, num jogo de tempo, que só um autor como Carlos de Oliveira poderia criar, "o passado quando incompletamente vivido transfere-se
23. Ibidem, p. 142.

24. Ibidem, p. 143.

25. OLIVEIRA, Carlos. $O$ aprendiz de feiticeiro, 2004, p. 141.

26. Ibidem, p. 141.

27. OLIVEIRA, Carlos. Trabalho poético, 1982, p. 21.

28. Ibidem, p. 55.

29. Ibidem, p. 54.

30. OLIVEIRA, Carlos. $O$ aprendiz de feiticeiro, 2004, p. 142. 
31. Ibidem, p. 142.

32. Ibidem, p. 143.

33. PEIXOTO, Níobe Abreu. João Cabral e o poema dramático, 2001, pp. 140-141. (não na memória, mas fisicamente) para o futuro e fica à nossa espera, puro esboço, pronto a desenvolver-se" ${ }^{31}$.

Poucas vezes Oliveira falou tão abertamente sobre a sincronia de tempos, como na passagem acima sobre Osório. A sobreposição de tempos guarda em si um caráter ambivalente e muito contraditório. Por um lado, ela justifica-se no âmbito de combate politicamente compromissado, criando os "germes da transformação”; por outro, dá a ver imobilidade e frustração de muitas coisas, inclusive a do corpo ("não na memória, mas fisicamente”, diz ele acima, e eu acrescento: na memória física). Por sua vez, esses vetores se resolvem e não se resolvem na presença de um tempo da natureza, sobretudo, em suas derivas vegetal e mineral. Resolvem-se porque é sobre isso que os textos falam. Não se resolvem porque o "ponto fraco das utopias, porque têm um, consiste na sua qualidade de negócios perdidos a priori; belo mas (redundantemente) utópicos. A juventude reencontrada à nossa espera na derradeira esquina $\mathrm{da}$ vida? Ilusões”32.

Assim, o teatro adiado em Carlos de Oliveira colabora para essa noção de tempo e também deixa ver, sem textos exatamente dramáticos, essa obsessão processual, no entanto, dramática de sua obra, através da valorização não só de voz e gesto, mas também da encenação do autor como escritor e leitor. Cabral, como Oliveira, também desistiu de alguns textos dramáticos. É o que diz, em entrevista transcrita, à Níobe Abreu Peixoto, autora de João Cabral e o poema dramático, estudo sobre o Auto do Frade:

$\mathrm{N}-($...) E os dois estudos; aqueles sobre a casa da farinha e sobre o Adão Pernambucano?

JC - Isso não. Isso, agora que estou cego, não farei mais. Era uma ideia que eu tinha de fazer um auto que retratasse um dia numa casa de farinha. Mas, nem pensar. Não sei ditar. Eu tinha também a ideia de um poema longo, que seriam as memórias prévias de Adão pernambucano (...).

$\mathrm{N}$ - O senhor comentou, em outra ocasião que tinha as falas prontas...

JC - Tinha, mas destruí tudo. Era o Jerônimo de Albuquerque no alto de Olinda olhando para o Recife, que ainda não existia, e prevendo toda a história; tudo o que aconteceria com Pernambuco. Por isso eu chamei de memórias prévias. (...) Ele está se lembrando de coisas que ele não vai ver. Mas eu deixei para lá também... ${ }^{33}$

As razões para o abandono são inteiramente diferentes em Cabral e Oliveira. Mas neste caso me interessa ver que em ambos o teatro se coloca como projeto. Em Oliveira só se concretiza como uma obsessão processual em outros textos. Já Cabral, apesar de ter esses dois projetos acima não realizados, tem duas obras dramáticas, Morte e Vida Severina e Auto do 
Frade, e outras duas em que o teatro se impõe de maneira mais que evidente: Os Três Mal-Amados e Dois Parlamentos. Esse último é, segundo Cabral, uma espécie de recital, cuja ideia inicial surgiu de um espetáculo montado por Antônio Abujamra em Madrid em que "cinco ou seis pessoas enfileiradas de costas para a plateia (...) iam se virando, recitavam um poema de poetas brasileiros e tornavam a dar as costas"34. Assim como Os Três Mal-Amados, trata-se mais de um poema com vozes do que de um poema dramático com ação. A primeira parte, "Congresso no Polígono das Secas", tem como subtítulo o sugestivo "ritmo senador; sotaque sulista", como a mostrar que tudo no texto mesmo se passará no âmbito da voz. E tais vozes enumerarão características para "Cemitérios gerais/ onde não só estão os mortos”35, e é como se elas apresentassem certo distanciamento e indiferença digna de senadores que influenciam em decisões no Nordeste sem do Nordeste exatamente saber. Funcionam como indicações para vocalização do poema.

\author{
- Nestes cemitérios gerais \\ não há morte pessoal. \\ - Nenhum morto se viu \\ como modelo seu, especial. \\ -Vão todos com a morte padrão, \\ em série fabricada. \\ - Morte que não se escolhe \\ e aqui é fornecida de graça. \\ - Que acaba sempre por se impor \\ sobre a que já medrasse. \\ - Vence a que, mais pessoal, \\ alguém já trouxesse na carne. \\ - Mas afinal tem suas vantagens \\ esta morte em série. \\ - Faz defuntos funcionais, \\ próprios a uma terra sem vermes ${ }^{36}$
}

A sequência de travessões deixa ver a enumeração de vozes que por sua vez se desdobram na enumeração das estrofes, em uma série numericamente fora de ordem. Apesar de polifônico, o que o poema diz em verdade poderia ser dito por uma única voz dado seu caráter monotemático, que se avizinha em muito de Morte e Vida Severina, a despersonalização não da poesia, mas da vida, submetida a uma paisagem de injustiças sociais que tornam "padrão" o morrer "nada humano,/ que nem lembra um homem, se o foi,/ e no qual nada mostra/ se a morte doeu, ou dói”37. A segunda parte, "Festa na Casa-Grande”, já lança mão de um "ritmo deputado; sotaque nordestino", que está mais próximo da violência dessa paisagem, embora mostre também indiferença, tal como a fala sulista dos senadores. Aqui há a série fora da ordem numérica e os travessões que se acumulam para um discurso também monotemático. Tais vo-
34. Ibidem, p. 34.

35. NETO, João Cabral de Melo. A educação pela pedra e outros poemas, 2008, p. 105.

36. Ibidem, p. 109.

37. Ibidem, p. 111. 
38. Ibidem, p. 115.

39. Ibidem, p. 115.

40. BARBOSA, João Alexandre. João Cabral de Melo Neto, 2001, p. 62. zes falam não a partir do canavial ou do engenho, mas sim de dentro de uma festiva Casa-Grande, que pouco se importa com o "cassaco de engenho/ o cassaco da usina" ${ }^{3}$. Talvez a maior proximidade - mesmo que muita relativa - entre quem fala e sobre quem se fala apareça no vocabulário regional, como "cassaco" que é como se chamam os trabalhadores de engenho e usina. Como na primeira parte, o tema é a morte e a indistinção com que opera nessas paisagens:

- O cassaco é um só
com diferente rima.
- O cassaco do engenho
banguê ou fornecedor:
- A condição cassaco
é o denominador.
- O cassaco de engenho
de qualquer Pernambuco:
- Dizendo-se cassaco
se terá dito tudo.
- Seja qual for seu nome,
seu trabalho, seu soldo:
-Dizendo-se cassaco
se terá dito todos

A estrutura do poema, arranjada em vozes, talvez sirva para descentralizar o peso do que se fala, as mortes, descentralizar sem simplesmente pretender uma suposta despersonalização com um discurso em terceira pessoa, mas sim espalhar tal peso através de personagens, dar mais vida ao tema da morte, colocando-o na voz de personagens, que no caso influenciam diretamente, pois assumem um lugar de fala histórico e tal lugar dá sentidos ao texto. $O$ fato de ser não só um discurso político, mas ser um discurso de políticos historicamente localizáveis (ritmo senador e ritmo deputado; sotaque sulista e sotaque nordestino) aumenta a espessura crítica do texto, dando camadas de humor. Trata-se do desencontro entre a função social das vozes que falam e sobre o que elas falam. São as vozes de governantes denunciando a gravidade da situação e isso, pelo poema, é o máximo que podem fazer. Para João Alexandre Barbosa, "ao poeta não resta senão ironizar as posições de mando, ou de desmandos, da classe dominante" ${ }^{40}$. Essa ironia pode se concretizar ou não, penso, porque o fato de haver um desencontro entre o que o político diz, como diz e o fato de ele ser político não é ruim para o político, mas para o "cassaco". Tal desencontro não prejudica nem deputados nem senadores, ao contrário tal discurso pode mantê-los onde já estão na "Casa-Grande” e no "Congresso". É um poema contraditório, belamente contraditório, porque acredita nos desencontros, a mesma voz que denuncia é a responsável em grande parte pelo mal denunciado. 
Se isso se desdobra para o poema, a contradição aumenta, porque em parte ele assume a responsabilidade também. Por mais que escreva na direção do ritmo e sotaque do cassaco, a voz a partir de onde ele fala tem mais afinidades com o ritmo deputado e senador, embora não quisesse ter. Para Antônio Carlos Secchin, "a pouco e pouco se vai configurando um leque de captações que subtrai ao trabalhador nordestino quaisquer hipóteses de uma postura crítica frente à existência, do mesmo modo como o 'ritmo deputado' já lhe furtara a $\left.v z^{41}\right)$. O mais interessante é que a voz furtada do sertanejo se metamorfoseia em muitas vozes dos políticos, que no entanto são monotemáticas, por estarem talvez subordinadas ao poema, poema que fez delas a sua voz. É como se fosse uma série de deslocamentos de vozes: do sertanejo aos políticos, dos políticos ao poema.

O saldo final é que o texto assume, com todas as letras, a responsabilidade pelo mal: “- É sempre a mesma pose,/ sem nenhum grito, gesto" ${ }^{42}$. Para além da mudez do cassaco que o poema a um só tempo confirma e passa por cima, mais ambíguo ainda é ver, por fim, que "Todos morrem em prosa,/ como foram, ou dormem”, pois não se sabe se o poema é o contrário da prosa, portanto seria ele um espaço de sobrevida desses cassacos; ou se, como queria Cabral, o poema é uma deriva poética da prosa - "Quiero que compogamos io/ e tú una prosa" ${ }^{43}$-, desta forma confirmando-se o texto também como responsável pelas mazelas do sertanejo.

O Auto do Frade (poema para vozes) é bem diferente de Dois Parlamentos. Primeiro, porque uma estrutura dramática mais normativa se impõe ao texto. Segundo, porque há claramente uma ação a se desenrolar. Junto com os textos dramáticos abandonados, $A$ casa da Farinha e Adão Pernambucano, o Auto do Frade seria uma tentativa de historicizar ainda mais o Pernambuco de sua obra. O que é curioso, pois liga essa vontade de história ao recurso das vozes em texto escrito, na medida em que os três textos têm elementos dramáticos. Enfim, a Via Crucis de Frei Caneca, devido ao seu desejo de fusão "entre a justeza e a justiça" ${ }^{4}$, coordena muitas vozes algumas individuais e outras coletivas. Não há muitos diálogos e eles estão circunscritos aos momentos em que há vozes individuais. A maior parte do tempo, há uma espécie de coro, distante do coro grego, que é o responsável, em grande parte, pela narração dos fatos. Como os diálogos são em pouco número no texto, o que acaba por se destacar é a presença do monólogo, tal qual já tinha ocorrido em Os Três Mal-Amados. Níobe Abreu Peixoto avisa: "Quando nos aproximamos do Auto do frade (poema para vozes) escutamos vozes que falam, mas que, na realidade, pouco dialogam entre si ${ }^{45}$. Em Morte e Vida Severina também há muitos monólogos, mas não se pode dizer que seja um tex-
41. SECCHIN, Antonio Carlos. João Cabral: a poesia do menos e outros ensaios cabralinos, 1999, p. 180.

42. NETO, João Cabral de Melo. A educação pela pedra e outros poemas, 2008, p. 112.

43. Idem, Morte e Vida Severina e outros poemas, 2007, p. 17.

44. NETO, João Cabral de Melo. A escola de facas / Auto do frade, 2008, p. 133.

45. PEIXOTO, Níobe Abreu. João Cabral e o poema dramático, 2001, p. 73. 
46. NETO, João Cabral de Melo. A escola de facas / Auto do frade, 2008, p. 151.

47. Ibidem, p. 164.

48. Ibidem, p. 167.

49. Ibidem, p. 149.

50. Ibidem, p.133.

51. Ibidem, p. 133.

52. Ibidem, p. 133. to com monólogos articulados, como é o caso do poema sobre Frei Caneca. As duas principais vozes que articulam a ação do poema é a voz de "A gente nas calçadas" (que, conforme muda o lugar, se torna "A gente no adro", "A gente no largo" e "Um grupo no pátio") e a voz do frade (que desdobra a voz da personagem João Cabral do poema). As vozes das gentes são responsáveis, como disse, pela narração e também pelo cenário: "- A procissão é o recorrido/ que vai de uma igreja a outra igreja./ - Mas nesta vai nosso caminho/ não a igreja, mas fortaleza" 46 ou "- Enquanto isso tudo, ele espera/ sentado nos degraus da forca./ - Como se não fosse com ele/ o corre-corre em sua volta" ${ }^{\$ 7}$. Há outros momentos, no entanto, em que elas caminham de um tom narrativo para um meditativo: “- Esperar é viver num tempo/ em que o tempo foi suspendido./ - Mesmo sabendo o que se espera,/ na espera tensa ele é abolido./ - Se quer que chegue ou que não,/ numa espera o tempo é abolido./ E o tempo longo mais encurta/ o da vida, é como um suicídio" ${ }^{48}$.

O trecho acima, que mostra o frade esperando a execução, em verdade é uma reflexão, na esteira de um mote de Vieira, sobre a morte que a vida vai tornando próxima. Frei Caneca morre aos 45 anos e, mesmo no século XIX, não é propriamente um homem idoso cujo "tempo logo mais encurta/ o da vida”; parece que o autor falava através dessas vozes mais de si do que do protagonista do auto. Por falar em Cabral, quando Frei Caneca fala, ouve-se um frade desejoso de uma cidade de "uma civil geometria" escrita ${ }^{49}$ : "Sei que o mundo jamais é/ a página pura e passiva./ O mundo não é uma folha/ de papel, receptiva:/ o mundo tem alma autônoma,/ é de alma inquieta e explosiva" ${ }^{50}$. De que Caneca fala nos versos anteriores senão da força e excesso do mundo que dificulta em muito a tarefa de contê-lo? Caneca desdobra-se em Cabral, melhor, na personagem Cabral. Tanto que a analogia proposta de contenção é a do texto, mesmo que pela negativa: "O mundo não é uma folha/ de papel, receptiva”, porque o mundo é uma folha de papel a ser domada. "Risco nesse papel praia,/ em sua brancura crítica/ que exige sempre a justeza/ em qualquer caligrafia" ${ }^{51}$. Ordenar "o mundo" é o que quer Caneca e, como se sabe, de certa forma também a literatura de Cabral quis exercer sobre este mesmo mundo um tipo de ordenação. Usar o verso "que exige que as coisas nele/ sejam de linhas precisas;/ e que não faz diferença/ entre a justeza e a justiça" ${ }^{52}$. Frei Caneca levou seu plano longe, mas ficou distante de concretizá-lo, pois domar o mundo era concretizar a Confederação do Equador, movimento emancipatório e republicano que se articulou no nordeste brasileiro em 1824. A Confederação do Equador foi impedida por D. Pedro, que puniu seus idealizadores, entre os quais, Frei Caneca. 
Repito: o frade levou seu plano longe, mas ficou distante de concretizá-lo. Resta saber o quão longe foi Cabral em seu plano de domar o mundo através "de linhas precisas". Sei que foi longe, mas a analogia entre ele e Caneca é uma indicação que tal plano também desdobra o de Caneca e sua principal consequência: "- Está triste, ainda mais corcunda,/ de artritismo ou tuberculose/ (...) - Assim, não o podemos ver mais?/ Quando o veremos estará morto?/ - Ver, não. Ouviremos sua morte,/ quem de todo ainda não está mouco" ${ }^{33}$. A fusão entre a voz da personagem Cabral e da personagem Caneca é tão grande que da boca do padre ouvimos esses versos irmãos dos de "Dúvidas apócrifas de Marianne Moore" de Agrestes:

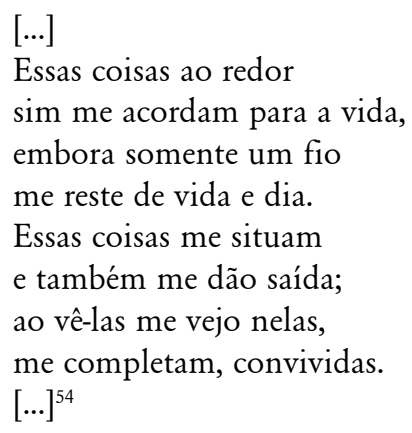

A ideia de se reconhecer nas coisas é a tônica do mencionado poema de Agrestes. Tal reconhecimento se desloca para a relação Cabral e Caneca, tornando ainda mais o frade uma espécie de alter ego cabralino. Em um dos momentos mais interessantes de Auto do Frade, a voz de Caneca utiliza como que aquela "memória prévia" que Cabral disse que utilizaria no poema abandonado Adão Pernambucano. E tal memória prévia aponta para coisas cabralinas, i.e., as referências em que a personagem Cabral se reconhece. Por exemplo, no trecho: "sob o sol de alma marinha,/ sob o sol inabitável/ que dirá Sophia um dia,/ vou revivendo os quintais" ${ }_{55}$, o poema alinha a experiência da paisagem em Caneca à experiência da paisagem em Sophia de Mello Brayner Andressen, cuja poesia está fortemente ligada a uma justeza solar e mediterrânea da vida e do verso, que, aparte o acento grego, guarda grande afinidade com a poesia de Cabral. Outro momento é quando o frade fala sobre a mortalha branca, e, ao fazer isso, evoca um poema antigo de Cabral: "Não penso que ainda venha/ a vestir outra camisa./ Certo também é mortalha/ e nela não sairei da vida" ${ }^{56}$. Isso traz de volta Psicologia da Composição: "Saio de meu poema/ como quem lava as mãos.// (...) Talvez alguma concha/ dessas (ou pássaro) lembre,/ côncava, o corpo do gesto/ extinto que o ar já preencheu;// talvez, como a camisa/ vazia, que despi." ${ }^{57}$.

Sair do poema, lavar as mãos e tirar uma camisa, no poema da década de 40, versus vestir outra camisa e sair da vida,
53. Ibidem, p. 170.

54. Ibidem, p. 115.

55. Ibidem, p. 130.

56. Ibidem, p. 152.

57. NETO, João Cabral de Melo. O cão sem plumas, 2007, p.121. 
58. Ibidem, p.121.

59. Idem. A escola de facas / Auto do frade, 2008, p. 152.

60. Ibidem, p. 152.

61. Ibidem, p. 133.

62. Ibidem, p. 130.

63. Ibidem, pp. 152-153.

64. ESCOREL, Lauro. A pedra e o rio - uma interpretação de João Cabral, 2001, p. 136. no poema da década de 80 . Entre tirar a camisa e vesti-la outra vez, Cabral trocou - passados quarenta anos - o substantivo: não mais sair do poema, mas sim da vida. Em Psicologia da Composição, ele continua: "Esta folha branca/ me proscreve o sonho,/ me incita o verso/ nítido e preciso" ${ }^{58}$.

Em Auto do Frade o mesmo branco assume outro registro em relação ao de Psicologia da Composição, essa diferença talvez seja análoga àquela entre, de um lado, tirar a camisa e sair do poema e, do outro, vestir a camisa (mortalha) e sair da vida. Eis o trecho: "Será que a morte é de branco,/ onde coisa não habita,/ ou, se habita, dá na soma/ uma brancura negativa"59. É então que surge a "memória prévia" no poema, como retomada do branco inaugural de Psicologia da Composição: "Ou será que é uma cidade/ toda de branco vestida,/ toda de branco caiada/ como Córdoba e Sevilha,/ como o branco sobre branco/ que Malevitch nos pinta/ e com os ovos de Brancusi/ largados pelas esquinas?" 60 . Córdoba, Sevilha, Malevitch e Brancusi fazem parte do arsenal cultural de Cabral, "coisas ao redor" que o "acordam para a vida", coisas que por sua vez estão ligadas ao branco construtivista de Psicologia da Composição e à utopia de Frei Caneca em construir "uma cidade solar" ${ }^{\prime 61}$.

Mas - da mesma forma que em Oliveira há uma poesia adiada, não coincidente consigo mesma, voz que se enche de um silêncio caligráfico e que vai na direção da natureza - em Cabral, é como se essas “coisas" que o "situam”, não lhe dessem mais "saída", porque, como diz o frade, "Eu sei que no fim de tudo/ um poço cego me fita" ${ }^{62}$. É nesses termos que Cabral, na posse de outro objeto, "um poço", vê que o projeto de Caneca está mais próximo de uma paixão - via crucis, no entanto, esvaziada de sentimento religioso - do que propriamente de um projeto construtivista nos moldes de uma modernidade. Assim, ao retomar novamente Psicologia da Composição - poema representante daquele projeto - com a voz de Caneca o retoma em outra direção: "Se essa mortalha branca/ é bilhete que habita/ a essa morte, eu, que a receio,/ entro nela com alegria" ${ }^{63}$. Pergunto: qual mudança de sentido está em jogo entre despir uma camisa e vestir outra, entre sair do poema e sair da vida, entre o branco de Malevitch e o branco da mortalha, desdobrado em "poço cego que me fita"?

Por fim, Lauro Escorel em A pedra e o rio: "muitos poemas cabralinos revelam sua dramaticidade, se podemos dizer assim, em segundo grau" ${ }^{4}$. Para ele, tal caráter dramático decorre de uma relação tensa entre sujeito e objeto que passa pela dialética: “(...) o processo de criação poética de Cabral de Melo o situa, em verdade, naquele ponto tangencial em que 
o sujeito se introjeta no objeto e o objeto no sujeito numa interação dialética: estamos, assim, diante de um poeta essencialmente dramático" ${ }^{65}$.

Acredito que tal levantamento de afinidades que Cabral e Oliveira têm em comum - afinidades ligadas à voz, como no caso o drama e ou mesmo um impulso dramático - pode dar à aproximação entre ambos um caráter mais movente no que diz respeito aos sentidos que as obras deles podem comportar. Entre os sentidos mobilizados por essas questões de caráter performativos, encontra-se um em especial, a tensão entre ordem e desordem que logo pode ser desdobrada em outra: a tensão entre construtivismo e seu consequente extravio. O que Escorel fala sobre Cabral, estendo nesse caso também para Oliveira: "Poética que o leva, para recorrer às suas próprias palavras, a dar número à tragédia, geometria à vertigem e decimais à emoção. Intenção estética que explica o fato de que o dramatismo de seus poemas não se reveste nunca de um cunho pessoal direto e óbvio." ${ }^{66}$.

Tal tensão, dando "números à tragédia, geometria à vertigem e decimais à emoção”, talvez aponte para um movimento não exclusivamente dialético - "O sim contra o sim" de Cabral -, o que por sua vez inscreverá outro dimensionamento temporal, que talvez o caráter serial dessas duas obras deixe flagrar.
65. Ibidem, p. 131.

66. Ibidem, p. 138. 


\section{Referências}

ALVES, Ida Maria Santos Ferreira. O Aprendiz de Feiticeiro: a máquina nos meus olhos. In: Pessoa - revista de ideias. Lisboa: Casa Fernando Pessoa, nª 4, setembro de 2011, pp. 133-146.

BARBOSA, João Alexandre. João Cabral de Melo Neto. Coleção Folha Explica. São Paulo: Publifolha, 2001.

ESCOREL, Lauro. A pedra e o rio - uma interpretação de João Cabral. Rio de Janeiro. ABL: 2001.

NETO, João Cabral de Melo. A educação pela pedra e outros poemas. Rio de Janeiro: Objetiva, 2008.

A escola das facas/Auto do frade. Rio e Janeiro:

Objetiva, 2008.

. Morte e Vida Severina e outros poemas. Rio de Janeiro: Objetiva, 2007.

. O cão sem plumas. Rio de Janeiro: Objetiva, 2007.

OLIVEIRA, Carlos. O aprendiz de feiticeiro. Lisboa: Assírio \& Alvim, 2004.

___. Trabalho Poético. $2^{a}$ ed. Lisboa: Sá da Costa Editores, 1982.

OTTONI, Paulo. John Langshaw Austin e a Visão

Performativa da Linguagem. DELTA [online]. 2002, vol. 18, n. 1, pp. 117-143. ISSN 0102-4450.

http://www.scielo.br/scielo.php?script=sci_arttext\&pid=S010244502002000100005\#nt

PEIXOTO, Níobe Abreu. João Cabral e o poema dramático.

São Paulo: AnnaBlume, 2001.

SECCHIN, Antonio Carlos. João Cabral: a poesia do menos e outros ensaios cabralinos. Rio de Janeiro: Topbooks, 1999.

ZUMTHOR, Paul. Introdução à poesia oral. Belo Horizonte: Editora UFMG, 2010. 